\title{
Vertical migration as a response to UVR stress in Calanus finmarchicus females and nauplii
}

\author{
Anette Wold \& Fredrika Norrbin
}

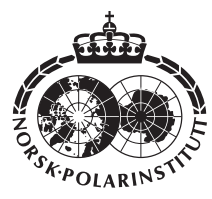

\begin{abstract}
We conducted laboratory experiments to study the behavioural responses of Calanus finmarchicus females and nauplii exposed to artificial ultraviolet radiation (UVR) and photosynthetically active radiation (PAR). Both nauplii and females migrated downwards when exposed to UVR. Nauplii reacted mainly to UV-B radiation, while females responded also to UV-A. Nauplii were also collected in the field to check if vertical distributions supported the experimental findings. Light measurements in Vestfjorden showed that plankton were exposed to quite low doses of UVR most of the time. However, on days with a thin ozone layer, clear sky and low turbidity UV-B doses in the surface waters might be harmful. Strong turbulence in the surface layer prevents nauplii from adjusting their position, exposing them to fluctuating levels of UVR due to vertical mixing. Under calm conditions, however, copepods could migrate sufficiently to avoid harmful UVR doses.
\end{abstract}

A. Wold, Norwegian Polar Institute, Polar Environmental Centre, NO-9296Tromsø, Norway, anette@npolar no; F. Norrbin, Norwegian College of Fishery Science, University of Tromsø, Breivika, NO-9037 Tromsø, Norway.

Reports of a thinning ozone layer near the poles have triggered an increased interest in the physiological and ecological effects of ultraviolet radiation (UVR) on marine organisms. Although the increase in UVR in Arctic regions is not as high or persistent as in Antarctica (Dahlback 2002), knowledge of the biological responses to changes in UVR levels are important for the understanding of shallow water biology in northern high latitude areas as well. Maximum values of $U V-B_{305} \mathrm{~nm}$ in the middle of the day in Lofoten were reported to be $5 \cdot 10^{-3} \mathrm{Wm}^{-2} \mathrm{~nm}^{-1}$ in March and $1.1 \mathrm{Wm}^{-2} \mathrm{~nm}^{-1}$ in late May (Eilertsen \& Holm-Hansen 2000).

Reported effects of UVR on zooplankton include a reduction in productivity and increased mortality (Zagarese \& Williamson 2000), decreased hatching success and increased larval mortality (Damkaer et al. 1980; Karanas et al. 1981; Kouwenberg et al. 1999; Rodriguez et al. 2000; Speekmann et al. 2000; Tartarotti et al. 2000; Aarseth \& Schram 2002). The negative effects could be attributed to UV-B in most of the studies, while effects of UV-A were more ambiguous. Reported $\mathrm{LD}_{50}$ from UV-B in experiments with copepods ranges from 3.5-29 $\mathrm{kJm}^{-2}$. Eggs appear to be the most vulnerable and adults the least sensitive stage (Naganuma et al. 1997; Lacuna \& Uye 2001).

Since radiation in the UV spectrum is rapidly absorbed in water compared to visible light, planktonic organisms are exposed to variable doses and spectral compositions of light depending on their depth distribution. Small-scale downward movement would therefore be beneficial for organisms near the surface when UVR levels are high (Forward 1988; Ringelberg 1995). Such a phototactic response requires that the organisms have receptors for the specific wavelengths (Cushing 1951). UV receptors have been found in the 
freshwater cladoceran Daphnia magna (Macagno \& Smith 1990) and D. pulex may also react to UVR by downward migration (Hessen \& van Donk 1994; Leech \& Williamson 2001). A migratory response has also been reported for copepods exposed to UV-B light (Aarseth \& Schram 1999; Speekmann et al. 2000). Retinular cells contain structures that can differentiate between different wavelengths, but it is unclear whether the nauplius eye of copepods can do this (Cronin et al. 1994).

The present study is concerned with smallscale vertical migration as a strategy to avoid deleterious UVR in the calanoid copepod Calanus finmarchicus (Gunnerus). Because it spawns in surface waters during the phytoplankton spring bloom (Marshall \& Orr 1953), eggs and nauplii are susceptible to enhanced UVR levels (Rodriguez et al. 2000). C. finmarchicus is important in the pelagic food web (Wiborg 1954; Tande 1988), and the nauplii are food for cod larvae, among other species (Poulet et al. 1995). Our hypothesis was that an increase in UVR would cause nauplii and females to move deeper in the water column. For this to occur, the copepods must be able to (1) sense radiation in the UV region, and (2) respond by downward migration under ambient turbulent conditions.

Laboratory experiments with artificial light were conducted to study copepod sensitivity to specific wavelengths. Samples of nauplii, subsurface light measurements and turbulence measurements were also collected to investigate if in situ vertical distributions supported the experimental findings. This study was part of a larger EU-funded project-The Influence of UVR and Climate Conditions on Fish Stocks (UVAC): A Case Study of the Northeast Arctic Cod.

\section{Materials and methods}

Laboratory experiments were performed at Lofilab $\mathrm{A} / \mathrm{S}$ in Ure $\left(68^{\circ} 07^{\prime} \mathrm{N}, 12^{\circ} 45^{\prime} \mathrm{E}\right)$, Lofoten, in April and May 2001. Sampling of nauplii and copepods took place outside Ure, in Vestfjorden, between the Norwegian mainland and the Lofoten Islands $\left(67-69^{\circ} \mathrm{N}, 12-18^{\circ} \mathrm{E}\right)$. The sampling location outside Ure is ca. $50 \mathrm{~m}$ deep and exposed to south-easterly wind and currents.

\section{Laboratory experiments}

Zooplankton were collected with a $180 \mu \mathrm{m}$ mesh WP-2 net from 15-0 m. The samples were kept at ca. $7^{\circ} \mathrm{C}$ in 50 -litre containers covered with black plastic. Copepods were sorted under a Wild M5 stereo microscop. Healthy individuals were transferred into one-litre plastic beakers and kept dark until the experiments. We compared four different light treatments, achieved by wrapping different filters around $32 \mathrm{~cm}$ high glass measuring cylinders: photosynthetically active radiation (PAR) only (Rosco film, Roscolab); PAR and UV-A (Mylar film, DuPont Teijin Films); PAR, UV-A and UV-B (no filter); and dark (black plastic). The treatments will be referred to as PAR, PAR + UV$\mathrm{A}, \mathrm{PAR}+\mathrm{UV}-\mathrm{A}+\mathrm{UV}-\mathrm{B}$ and dark, respectively. One Phillips Ultraviolet-B TL 40W/12 fluorescent tube and one Phillips White TLD 36W/17 fluorescent tube were placed $30 \mathrm{~cm}$ above the cylinders. Cool white light tubes were mounted on each side. Irradiance was measured at the top of the measuring cylinders with a PUV-510 (Biospherical Instruments), and subsurface irradiance right beneath the surface and at the bottom of the cylinders (30 cm depth) was calculated (Table 1). Subsurface calculations were based on $20 \%$ loss in light intensity from air to water, which was the average value based on in situ measurements,

Table 1. Depth distribution experiment. Surface light intensities $\left(\mathrm{Wm}^{-2}\right)$ deriving from fluorescent white tubes and UVR tubes, and calculated subsurface irradiance right below the surface and at the bottom of the cylinders.

\begin{tabular}{|c|c|c|c|c|c|c|c|}
\hline \multirow[t]{2}{*}{ Wavelength } & \multicolumn{2}{|c|}{ Surface } & \multicolumn{2}{|c|}{$\begin{array}{l}\text { Subsurface } \\
(0 \mathrm{~cm} \text { depth })\end{array}$} & \multicolumn{2}{|c|}{$\begin{array}{c}\text { Bottom } \\
\text { (30 cm depth) }\end{array}$} & \multirow[t]{2}{*}{$K_{d}$} \\
\hline & White & UVR & White & UVR & White & UVR & \\
\hline $305 \mathrm{~nm}$ & $3.0 \cdot 10^{-4}$ & $9.8 \cdot 10^{-2}$ & $2.5 \cdot 10^{-4}$ & $7.7 \cdot 10^{-2}$ & $2.0 \cdot 10^{-4}$ & $6.5 \cdot 10^{-2}$ & 0.57 \\
\hline $320 \mathrm{~nm}$ & $5.0 \cdot 10^{-4}$ & $2.7 \cdot 10^{-2}$ & $4.0 \cdot 10^{-4}$ & $2.1 \cdot 10^{-2}$ & $3.0 \cdot 10^{-4}$ & $1.7 \cdot 10^{-2}$ & 0.66 \\
\hline $340 \mathrm{~nm}$ & $7.0 \cdot 10^{-4}$ & $1.1 \cdot 10^{-2}$ & $6.0 \cdot 10^{-4}$ & $9.0 \cdot 10^{-3}$ & $5.0 \cdot 10^{-4}$ & $7.0 \cdot 10^{-3}$ & 0.57 \\
\hline $380 \mathrm{~nm}$ & $5.0 \cdot 10^{-3}$ & $1.5 \cdot 10^{-3}$ & $4.0 \cdot 10^{-3}$ & $1.0 \cdot 10^{-4}$ & $3.6 \cdot 10^{-3}$ & $1.0 \cdot 10^{-3}$ & 0.33 \\
\hline PAR (400-700 nm) & 18 & $2.6 \cdot 10^{-2}$ & 15 & $8.0 \cdot 10^{-4}$ & 13 & $1.8 \cdot 10^{-4}$ & 0.28 \\
\hline
\end{tabular}


and minimum $K_{d}$ values measured during spring 2001 were used for the bottom light calculations. Total light intensities ( $\mathrm{W} \mathrm{m}^{-2}$ ) for the three different treatments (PAR, PAR +UV-A, PAR + UV$\mathrm{A}+\mathrm{UV}-\mathrm{B})$ were calculated based on planimetric integration (Table 2). The calculations were based on measurements and calculations shown in Table 1; a total cut-off at $320 \mathrm{~nm}$ for Rosco and $380 \mathrm{~nm}$ for Mylar was assumed. The experiment was set up as a randomized block design (Hurlbert 1984). Four replicates of complete blocks were run consecutively for nauplii, and three replicates for females. In each experiment, ca. 100 individuals of either stage NI-III or NIV-VI, or 30 adult females were added to each of the four cylinders and exposed for $30 \mathrm{~min}$. Nauplii were siphoned out in four depth intervals using silicon tubing, and counted under a Wild M5 stereo microscope, while the distributions of females were determined visually.

Because distributions were either skewed or bimodal (Fig. 1), the data for each developmental stage were analysed using log-linear analysis (Systat ver. 10.2). This method is based on logarithmical transformation of data to find the linear model that best and most simply describes the observed data. This allowed us to test different factors and their interaction for statistical differences using the original distribution frequencies. The starting point was the saturated model:

\section{[OBSERVED FREQUENCY] = \\ TREATMENT + DEPTH + REPLICATE + TREATMENT*DEPTH + DEPTH*REPLICATE + TREATMENT*REPLICATE + TREATMENT*DEPTH*REPLICATE}

The model was modified by stepwise removal of those terms that did not contribute to the fit of the model, until a good fit was achieved. For that model, the different treatments (PAR, PAR+UVA, PAR+UV-A+UV-B and dark) were subsequently removed to find which treatment contributed most to the model.

\section{Field investigation}

Meteorological data for the period MarchMay were obtained from the weather station of the Norwegian Meteorological Institute at Skrova. The ozone layer thickness was recorded by a Total Ozone Mapping Spectrometer over Andenes $\left(69^{\circ} 18^{\prime} \mathrm{N}, 16^{\circ} 00^{\prime} \mathrm{E}\right)$ and retrieved from http://jwocky.gsfc.nasa.gov.

Sub-surface UVR/PAR profiles were taken with a Biospherical Instruments PUV 500, and surface irradiance with PUV 510. Both are multichannel bandwidth filter instruments (with a bandwidth of $10 \mathrm{~nm}$ at full width half maximum) centred at UV-B (305 - $320 \mathrm{~nm}), \mathrm{UV}-\mathrm{A}(340$ - $380 \mathrm{~nm})$ in $\mu \mathrm{W}$ $\mathrm{cm}^{-2} \mathrm{~nm}^{-1}$ and integrated PAR (400-700 nm) in $\mu$ mol quanta $\mathrm{cm}^{-2} \mathrm{~s}^{-1}$. The atmospheric sensors were placed on shore at $5 \mathrm{~m}$ above the sea surface. All measurements were converted to $\mathrm{Wm}^{-2}$ (Eilertsen \& Holm-Hansen 2000), except for the daily integrated doses, which were computed for UV-B, UV-A and PAR. The diffuse extinction coefficient $\left(K_{d}\right)$ was calculated according to Lalli \& Parsons (1997).

Temperature and salinity were measured at the surface using a TPS MC-84.

A Nortek Acoustic Doppler Current Profiler registered currents using a frequency of $8 \mathrm{~Hz}$.

Nauplii were collected using a 3 litre Ruttner

Table 2. Depth distribution experiment. Total integrated light intensities $\left(\mathrm{Wm}^{-2}\right)$ for the three different treatments, and their spectral components.

\begin{tabular}{lcccccc}
\hline & \multicolumn{2}{c}{ Surface } & \multicolumn{2}{c}{ Subsurface } & \multicolumn{2}{c}{ Bottom $(30 \mathrm{~cm})$} \\
& White & UVR & White & UVR & White & UVR \\
\hline $\begin{array}{l}\text { PAR + UV-A + UV-B treatment } \\
(305-700 \mathrm{~nm})\end{array}$ & 18.13 & 1.75 & 15.03 & 1.35 & 13.09 & 1.13 \\
$\begin{array}{l}\text { PAR + UV-A treatment } \\
(320-700 \mathrm{~nm})\end{array}$ & 18.12 & 0.92 & 15.03 & 0.62 & 13.09 & 0.52 \\
$\begin{array}{l}\text { PAR treatment } \\
(400-700 \mathrm{~nm})\end{array}$ & 18.00 & 0.03 & 15.00 & 0.02 & 13.00 & 0.02 \\
UV-B $(305-320 \mathrm{~nm})$ & 0.006 & 0.94 & 0.005 & 0.74 & 0.004 & 0.62 \\
UV-A $(320-380 \mathrm{~nm})$ & 0.12 & 0.79 & 0.03 & 0.60 & 0.09 & 0.50 \\
PAR $(400-700 \mathrm{~nm})$ & 18.00 & 0.03 & 15.00 & 0.017 & 13.00 & 0.02 \\
\hline
\end{tabular}


water bottle at $0,1,2,3,4,5,7,10$ and $15 \mathrm{~m}$, deployed twice at each depth. The samples were filtered through a $45 \mu \mathrm{m}$ mesh sieve and preserved in a solution of $4 \%$ borax buffered formaldehyde and 1,2-propanediol (1:1) for later identification. Chlorophyll- $a$ was extracted in methanol and measured using a Turner Designs fluorometer (Holm-Hansen \& Rieman 1978). Phytoplankton samples were counted in two $\mathrm{ml}$ sedimenting chambers (Utermöhl 1931) using a Leitz DMIL inverted microscope.

\section{Results}

\section{Laboratory experiments}

Nauplii exposed to PAR+UV-A+UV-B were located deepest in the cylinders, and those exposed to either only PAR or darkness were found closest to the surface (Fig. 1). In the log-linear analyses, the model \{TREATMENT*DEPTH, TREATMENT, and TREATMENT*DEPTH*REPLICATE gave the best fit for NI-III (Table 3). This indicates that there was some difference between replicates, in addition to different abundance in the analysed depth intervals and between the experimental treatments. After removal of the PAR+UV-A+UV-B treatment, the TREATMENT term lost its effect. For NIV-VI, the model \{TREATMENT*DEPTH, DEPTH, TREATMENT, and TREATMENT*REPLICATE $\}$ gave the best fit (Table 3). UV-B was the most important factor in the treatment effect here as well. The females were located deep in the cylinders in both the PAR+UV-A and PAR+UV-A+UV-B treatments, but not in PAR and dark treatments (Fig. 1). For females, the model \{TREATMENT*DEPTH, DEPTH, TREATMENT, and TREATMENT* DEPTH*REPLICATE $\}$ gave the best fit (Table 3 ). The TREATMENT term lost effect slightly when the dark treatment was removed, while PAR

Table 3. Depth distribution experiments; results from log-linear modelling. The terms are listed in descending order of contribution. Terms are abbreviated thus: TRE = light treatment, DEP = depth, REP = replicate. The effect on the model fit of removing each of the treatments is described. Iterations $=50, \delta=0.5$. Probability that the model differs from the data is given in the last column.

\begin{tabular}{|c|c|c|c|c|}
\hline Experiment & Terms in model & df & Likelihood ratio $X^{2}$ & $\mathrm{P}$ \\
\hline NI-III & $\begin{array}{l}\text { TRE*DEP+TRE+ } \\
\text { TRE*DEP*REP }\end{array}$ & 12 & 11.8 & 0.45 \\
\hline \multirow[t]{4}{*}{$\begin{array}{l}\text { Effect of removal } \\
\text { of treatment }\end{array}$} & PAR & & No difference from model & \\
\hline & PAR + UV-A & & No difference from model & \\
\hline & $\mathrm{PAR}+\mathrm{UV}-\mathrm{A}+\mathrm{UV}-\mathrm{B}$ & & TRE less contribution & \\
\hline & Dark & & No difference from model & \\
\hline NIV-VI & $\begin{array}{l}\text { TRE } * \text { DEP+DEP+ } \\
\text { TRE + TRE*REP }\end{array}$ & 39 & 43.9 & 0.27 \\
\hline \multirow[t]{4}{*}{$\begin{array}{l}\text { Effect of removal } \\
\text { of treatment }\end{array}$} & PAR & & No difference from model & \\
\hline & $\mathrm{PAR}+\mathrm{UV}-\mathrm{A}$ & & No difference from model & \\
\hline & $\mathrm{PAR}+\mathrm{UV}-\mathrm{A}+\mathrm{UV}-\mathrm{B}$ & & TRE less contribution & \\
\hline & Dark & & $\begin{array}{l}\text { Little difference, DEP*REP } \\
\text { less contribution }\end{array}$ & \\
\hline Females & $\begin{array}{l}\text { TRE *DEP, } \\
\text { DEP, } \\
\text { TRE, } \\
\text { TRE *DEP*REP }\end{array}$ & 14 & 14.2 & 0.43 \\
\hline \multirow[t]{4}{*}{$\begin{array}{l}\text { Effect of removal } \\
\text { of treatment }\end{array}$} & PAR & & $\begin{array}{l}\text { TRE*DEP*REP less contribu- } \\
\text { tion }\end{array}$ & \\
\hline & $\mathrm{PAR}+\mathrm{UV}-\mathrm{A}$ & & No difference from model & \\
\hline & $\mathrm{PAR}+\mathrm{UV}-\mathrm{A}+\mathrm{UV}-\mathrm{B}$ & & No difference from model & \\
\hline & Dark & & $\begin{array}{l}\text { Little difference, TRE less } \\
\text { contribution }\end{array}$ & \\
\hline
\end{tabular}




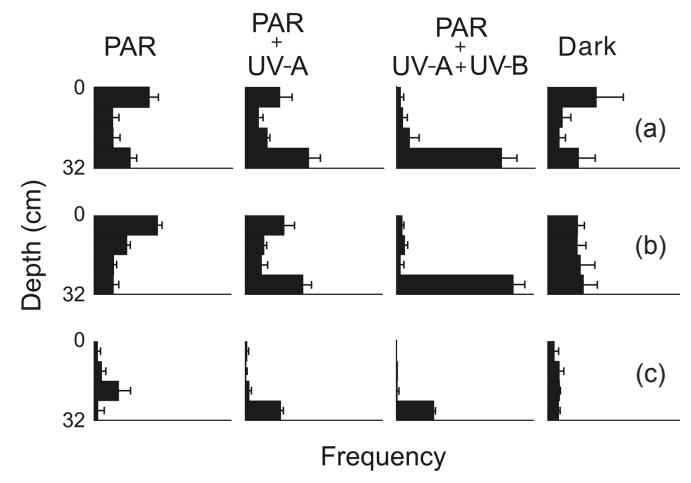

Fig. 1. Calanus finmarchicus depth distribution experiments. The copepod distribution in four depth intervals is shown for each developmental stage and experimental treatment. Error bars represent standard deviation. The $\mathrm{x}$ axis extends to the frequency of one in each pane. (a) NI-NIII $(n=4)$, (b) NIVNVI $(n=4)$ and $(c)$ females $(n=3)$.

seemed to be the cause of the three-way interaction (TREATMENT*DEPTH*REPLICATE). This was probably due to greater variation between the replicates in the PAR treatment than in the others (Fig.1).

\section{Field investigations}

The thickness of the ozone layer varied greatly throughout the sampling period. It was between 400 and 450 DU in March and at the beginning of April, but then decreased from late April until mid-May (350 - $400 \mathrm{DU})$. The weather was mostly cloudy, with a few sunny days.

The highest light intensities were measured in the middle of the day on 29 April $\left(\mathrm{UV}-\mathrm{B}_{320 \mathrm{~nm}}=0.13\right.$ $\mathrm{W} \mathrm{m} \mathrm{m}^{-2}, \mathrm{UVA}_{380 \mathrm{~nm}}=0.47 \mathrm{~W} \mathrm{~m}^{-2}$ and PAR $=307$ $\mathrm{W} \mathrm{m}^{-2}$ ). Nearly the same intensities were measured during cloudy days in the beginning of May, but only during short periods of time. Therefore the daily UVR doses were considerably higher during days with a clear sky (Table 4). UV-B was absorbed in the upper $m$ of the water column. At $5 \mathrm{~m}$ depth $\mathrm{UVB}_{305} \mathrm{~nm}$ was seldom measurable, while $\mathrm{UVB}_{320 \mathrm{~nm}}$ was reduced to $5 \%, \mathrm{UVA}_{380 \mathrm{~nm}}$ to $20 \%$ and PAR to $35 \%$ of that measured immediately below the surface (Fig. 2). Temperature varied from 3.8 to $4.3^{\circ} \mathrm{C}$, and salinity from 33.1 to $33.3 \mathrm{PSU}$ in the surface water. No CTD profiles were taken at the location outside Ure, but in nearby Henningsværstraumen there was a weak pycnocline at ca. $30 \mathrm{~m}(\Delta \sigma \mathrm{t}=0.4)$ during the same period (http://lupus.nfh.uit.no.)

Turbulence, especially in the vertical direction, varied depending on wind conditions. The calmest period was during the sunny days in late April (Fig. 3).

On the two days with weak vertical turbulence and relatively high UV-B intensities (28 - 29 April), few nauplii were located in the upper $3 \mathrm{~m}$ of the water column (Fig. 3). Later in the study period, vertical turbulence was higher, and there was more cloud cover and slightly lower UV$\mathrm{B}_{320 \mathrm{~nm}}$ intensities. The nauplii were then more evenly distributed, and also occurred in surface samples (Fig. 3). Chlorophyll- $a$ ranged from $0.05-2.2 \mu \mathrm{gl}^{-1}$ in the surface, and the concentration decreased slightly with depth on most of the sampling days. Thalassiosira nordenskioeldii and T. gravida were the most abundant species, and Phaeocystis pouchetii was present in the beginning of the period (M. Mommens, pers. comm.).

\section{Discussion}

The laboratory experiments suggest that Calanus finmarchicus nauplii and females can sense UV light. The reason why females responded more strongly to UV-A than the nauplii may be that the photosensory apparatus is better developed in females (Stearns \& Forward 1984). The cost of swimming may also be larger for nauplii than for females, and they may therefore be adapted to respond only to the more deleterious UV-B (Longhurst 1976). Ideally, all experimental treatments should have exactly the same total light intensity to avoid this factor influencing the distributions.
Fig. 2. Subsurface light profiles as percent of surface intensities (log scale), from Vestfjorden, 20 March 2001. (a) UV-B 305 $\mathrm{nm}$ (stippled line) and $320 \mathrm{~nm}$ (continuous line), (b) UV-A 340 $\mathrm{nm}$ (stippled line) and $380 \mathrm{~nm}$ (continuous line) and (c) PAR (400- $700 \mathrm{~nm})$.

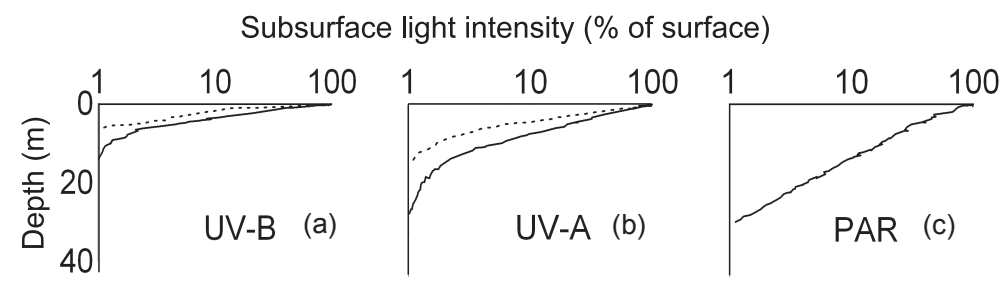




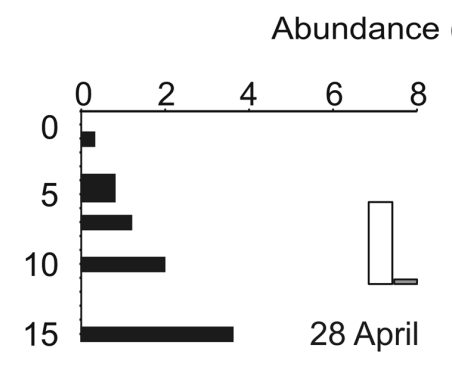

Fig. 3. Depth distribution of Calanus finmarchicus nauplii outside Ure. The small columns

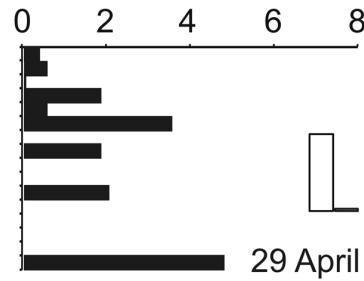
represent the vertical component of UV-B ${ }_{320 \mathrm{~nm}}$ radiation at the surface (unfilled column; values ranging from 0.091 to $0.14 \mathrm{Wm}^{-2}$ ) and turbulence (grey; velocities ranging from 0.004 to $0.2 \mathrm{~ms}^{-1}$ ).
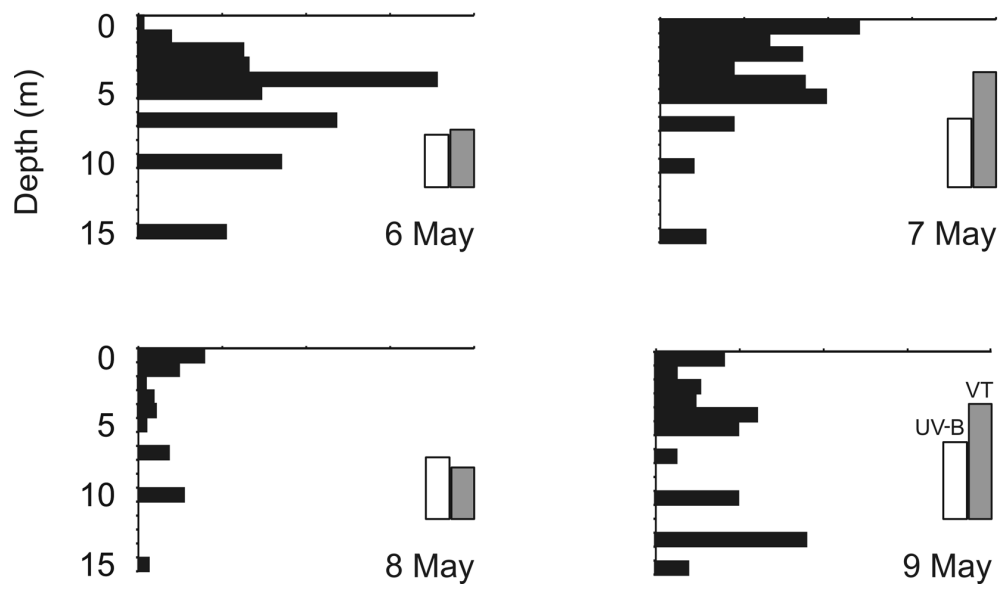

The differences in total light intensity between the PAR, PAR+UV-A and PAR+UV-A+UV-B treatments (Table 2) were probably too small to cause any differences in the response.

Aarseth \& Schram (1999) conducted similar experiments with $C$. finmarchicus $\mathrm{CV}$, but found no significant differences in depth distribution between $1 \mathrm{~m}$ cylinders exposed to UV-B $\left(3.3 \cdot 10^{-4}\right.$ $\mathrm{Wm}^{-2}$ ), PAR (12.8 $\mathrm{Wm}^{-2}$ ) and UV-B. However, copepods placed in beakers tried to escape from

Table 4. Ure 2001. Daily doses of UV-B (290 - $\left.320 \mathrm{~nm} ; \mathrm{kJm}^{-2}\right)$, UV-A (320-400 nm; kJm$\left.{ }^{-2}\right)$ and PAR 400-700 nm $(\mu \mathrm{mol}$ quanta $\left.\mathrm{cm}^{-2} \mathrm{~s}^{-1}\right)$.

\begin{tabular}{lccc}
\hline Date & $\begin{array}{c}\text { UV-B } \\
(290-320 \mathrm{~nm})\end{array}$ & $\begin{array}{c}\text { UV-A } \\
(320-400 \mathrm{~nm})\end{array}$ & $\begin{array}{c}\text { PAR } \\
(400-700 \mathrm{~nm})\end{array}$ \\
\hline 28 April & 28 & 390 & 3325 \\
29 April & 31 & 430 & 3456 \\
6 May & 31 & 830 & 1786 \\
7 May & 27 & 740 & 1535 \\
8 May & 28 & 860 & 1281 \\
9 May & 30 & 950 & 1124 \\
\hline
\end{tabular}

UV-B, but not PAR only, by swimming downwards (Aarseth \& Schram 1999). Experiments with Daphnia under full spectrum solar radiation demonstrated that a larger portion of individuals migrated downward in the presence of UV radiation than in UV radiation shielded treatments (Leech \& Williamson 2001). Speekman et al. (2000) noted that Tortanus dextrilobatus migrated $50 \mathrm{~cm}$ deeper in $2 \mathrm{~m}$ high columns when exposed to UV-B $\left(6.5 \mathrm{Wm}^{-2}\right)$ than when only PAR was present. Contrary to the results we present here, Bollens \& Frost (1990) found no significant difference in weighted mean depth between Acartia hudsonica exposed to natural UV-B and those protected by Mylar filters in an experimental field study.

In our experiments, copepods may have escaped from the surface layer because of toxic compounds produced from oxygen and organic compounds under conditions of elevated UV-B radiation The response of copepods to natural light conditions is difficult to evaluate, because advective processes and other environmental features interfere with behavioural responses. Despite 
these uncertainties, our field study revealed some tendencies in the depth distribution of $C$. finmarchicus nauplii. In situ distributions indicate that nauplii avoided the surface layer during periods of increased UVR and low levels of turbulence. Field sampling coincided with a change in weather from clear calm days to cloudier, windier days. Ontogenetic development may therefore have influenced distribution patterns between the earlier and later sampling occasions. In a canonical correspondence analysis testing correlation between environmental factors and the depth distribution of nauplii, the only factor that could explain the variance in depth distribution was time (data not shown). The environmental factors, especially light, were mainly a function of time, so their effect was difficult to separate from the effect of ontogenetic development (data not shown). The uniform distribution of nauplii in surface waters during wind events agrees with earlier investigations at George's Bank (off New England) and in the Mediterranean (Incze et al. 1996; Lagadeuc et al. 1997). The vertical turbulence at $5 \mathrm{~m}$ depth outside Ure varied from 4 to $200 \mathrm{~mm} \mathrm{~s}^{-1}$, while the swimming speed of nauplii is 0.5-2 $\mathrm{mm} \mathrm{s}^{-2}$ (Mauchline 1998). Naupliar movement therefore depends mainly on the mixing regime, while females (swimming speed 18.3-29.7 $\mathrm{mm} \mathrm{s}^{-2}$; Mauchline 1998) should be able to modify their vertical position also under weakly turbulent conditions.

The total UV-B dose a copepod receives depends on the attenuation properties of the water and the time spent at different depths. Model simulations from Oslofjorden showed that $C$. finmarchicus $\mathrm{CV}$ would be protected from harmful UVR doses $\left(\mathrm{LD}_{10}=21.5 \mathrm{kJm}^{-2}\right)$ if they avoided the upper $1 \mathrm{~m}$ of the water column or if the mixed layer was greater than $7 \mathrm{~m}$ (Aarseth \& Schram 2002). Provided that $\mathrm{LD}_{10}$ for $C$. finmarchicus females in Lofoten is similar to that cited by Aarseth \& Schram (2002), copepods would only receive harmful doses during periods with UV-B doses greater than $77 \mathrm{kJm}^{-2}$, which was an average value during spring 2002, combined with low attenuation $\left(K_{d}=0.07 \mathrm{~m}^{-1}\right.$, the minimum value measured during spring 2002) in the water (Wold 2002). The amounts of UV-B to which the copepods are exposed in this area are therefore strongly regulated by the attenuation properties of the water, and vertical mixing. The attenuation of light is high most of the time during spring and would prevent exposure to any harmful UVR in these areas (Wold 2002). This agrees with estimated mortality rates of $C$. finmarchicus eggs under different meteorological and hydrological conditions in the Gulf of. St Lawrence (Browman et al. 2000). They showed that optical water quality and vertical distribution within the mixed layer had greater effects on the UV-B exposure of $C$. finmarchicus eggs than potential ozone depletion. Lower doses could also cause sublethal effects such as genetic damage that might be carried on to the next generation. Accumulation of such genetic damage might be harmful for the population over time (Zagarese \& Williamson 2000).

The relatively thick ozone layer and frequent cloud cover over northern Europe usually prevents high UV-B doses at the surface. Rapid attenuation in the water column and strong wind and tidal driven mixing also limits the UV-B exposure of marine plankton. In Vestfjorden, copepods spend most of their time at depths with little or no UV-B because of the mixing regime. However, a combination of a thin ozone layer, clear skies and water and little mixing could result in harmful UV-B doses in surface layers. During such events, it would be beneficial for copepods to avoid the upper $1 \mathrm{~m}$ of the water column. Since $C$. finmarchicus is an important prey organism for carnivorous zooplankton and fish larvae, decreased recruitment due to increased UV-B would affect higher trophic levels. If increased UV-B doses force nauplii deeper in the water column, the food supply in surface waters will be reduced.

Acknowledgements.-We would like to thank the personnel at Lofilab A/S, colleagues in the UVAC project, and the crew on the RV Hyas, RV Johan Ruud and RV Jan Mayen for help during cruises and fieldwork. Einar M. Nilssen kindly helped us with the log-linear analyses. A special thanks to Hans Christian Eilertsen for making this work possible.

\section{References}

Aarseth, K. A. \& Schram, T. S. 1999: Wavelength-specific behaviour in Lepeophtheirus salmonis and Calanus finmarchicus to ultraviolet and visible light in laboratory experiments (Crustacea: Copepoda). Mar. Ecol. Prog. Ser. 186, 211-217.

Aarseth, K. A. \& Schram, T. S. 2002: Susceptebility to ultraviolet radiation in Calanus finmarchicus and Lepeophtheirus salmonis and the adaptive value of external filtering (Crustacea: Copepoda). J. Plankton Res. 24, 661-679. 
Bollens, S. M. \& Frost, B. W. 1990: UV light and vertical distribution of marine planktonic copepod Acartia hudsonica Pinhey. J. Exp. Mar. Biol. 137, 89-93.

Browman, H. I., Rodriguez, C. A., Beland, F., Cullen, J. J., Davis, R. F., Kouwenberg, J. H. M., Kuhn, P. S., McArthur, B., Runge, J. A., St-Pierre, J. F. \& Vetter, R. D. 2000: Impact of ultraviolet radiation on marine crustacean zooplankton and ichthyoplankton: a synthesis of results from the estuary and Gulf of St. Lawrence, Canada. Mar. Ecol. Prog. Ser. 199, 293-311.

Cronin, T. W., Marshall, J. M., Caldwell, R. L. \& Shashar, N. 1994: Specialization of retinal function in the compound eyes of Mantis shrimp. Vis. Res. 34, 2639-2656.

Cushing, D. H. 1951: The vertical migration of planktonic Crustacea. Biol. Rev. 26, 158-192.

Dahlback, A. 2002: Recent changes in surface ultraviolet solar radiation and stratospheric ozone at a High Arctic site. In D. O. Hessen (ed): UV radiation and Arctic ecosystem. Pp. 1-20. Berlin: Springer.

Damkaer, D. M., Dey, D. B., Heron, G. A. \& Prentice, E. F. 1980: Effects of UV-B radiation on near-surface zooplankton of Puget Sound. Oecol. (Berl.) 44, 149-158.

Eilertsen, H. C. \& Holm-Hansen, O. 2000: Effects of high latitude UV radiation on phytoplankton and nekton modelled from field measurments by simple algorithms. Polar Res. 19, 173-182.

Forward, R. B. 1988: Diel vertical migration-zooplankton photobiology and behavior. Oceanogr. Mar. Biol. 26, 361393.

Hessen, D. O. \& van Donk, E. 1994: Effects of UV-radiation of humic water on primary and secondary production. Water, Air Soil Pollut. 75, 3-4.

Holm-Hansen, O. \& Rieman, B. 1978: Chlorophyll a determination: improvement of the methodology. Oikos 30, 438447.

Hurlbert, S. H. 1984: Pseudoreplication and the design of ecological field experiments. Ecol. Monogr. 54, 187-211.

Incze, L. S., Aas, P. \& Ainaire, T. 1996: Distributions of copepod nauplii and turbulence on the southern flank of Georges Bank: implications for feeding by larval cod (Gadus morhua). Deep-Sea Res. 43, 7-8.

Karanas, J. J., Worrest, R. C. \& van Dyke, H. 1981: Impact of UV radiation on the fecundity of the copepod Acartia clausii. Mar. Biol. 65, 125-133.

Kouwenberg, J. H. M., Browman, H., Cullen, J. J., Davis, R. F., St. Pierre, J. F. \& Runge, J. A. 1999: Biological weighting of ultraviolet $(280-400 \mathrm{~nm})$ induced mortality in marine zooplankton and fish. I Atlantic cod (Gadhus morhua) eggs. Mar. Biol. 134, 269-284.

Lacuna, D. G. \& Uye, S. I. 2001: Influence of mid-ultraviolet (UVB) radiation on the physiology of the marine planktonic copepod Acartia omorii and the potential role of photoreactivation. J. Plankton Res. 23, 143-156.

Lagadeuc, Y., Boule, M. \& Dodson, J. J. 1997: Effect of vertical mixing on the vertical distribution of copepods in coastal waters. J. Plankton Res. 19, 1183-1204.

Lalli, C. M. \& Parsons, T. R. (eds.) 1997: Biological oceanography - an introduction. East Kilbride: Thomson Litho Ltd.

Leech, D. M. \& Williamson, C. E. 2001: In situ exposure to ultraviolet radiation alters the depth distribution of Daphnia. Limnol. Oceanogr. 46, 416-420.

Longhurst, A. R. 1976: Vertical migration. In D. H. Cushing \& J. J. Walsh (eds): The ecology of the sea. Pp. 116-137. Philadelphia: Saunders.

Macagno, E. R. \& Smith, K. C. 1990: UV photoreceptors in the compound eye of Daphnia-Magna (Crustacea, Branchiopoda). A fourth spectral class in single ommatidia. $J$. Comp. Physiol. A Sens. Neural Behav. Physiol. 166, 597606.

Marshall, A. M. \& Orr, A. P. 1953: Calanus finmarchicus: egg production and egg development in Tromsø Sound in spring. Acta Borealia 5, 1-20.

Mauchline, J. 1998: The biology of calanoid copepods. San Diego: Academic Press.

Naganuma, T., Inoue, T. \& Uye, S. 1997: Photoreactivation of UV-induced damage to embryos of a planktonic copepod. J. Plankton Res. 19, 783-787.

Poulet, S. A., Laabir, M., Ianora, A. \& Miralto, A. 1995 Reproductive response of Calanus helgolandicus. 1. Abnormal embryonic and naupliar development. Mar. Ecol. Prog. Ser. 129, 1-3.

Ringelberg, J. 1995: An account of a preliminary mechanistic model of swimming behavior in Daphnia-its use in understanding diel vertical migration. Hydrobiologia 307, 161-165.

Rodriguez, C. A., Browman, H. I., Runge, J. A. \& St-Pierre, J. F. 2000: Impact of solar ultraviolet radiation on hatching of a marine copepod, Calanus finmarchicus. Mar. Ecol. Prog. Ser. 193, 85-93.

Speekmann, C. L., Bollens, S. M. \& Avent, S. R. 2000: The effect of ultraviolet radiation on the vertical distribution and mortality of estuarine zooplankton. J. Plankton Res. 22, 2325-2350.

Stearns, D. E. \& Forward, R. B. J. 1984: Photosensivity of the calanoid copepod Acartia tonsa. Mar. Biol. 82, 85-89.

Tande, K. S. 1988: An evolution of factors affecting vertical distribution among recruits of Calanus finmarchicus in three adjacent high latitude areas. Hydrobiologia 167/168, $115-126$.

Tartarotti, B., Cravero, W. \& Zagarese, H. E. 2000: Biological weighting function for the mortality of Boeckella gracilipes (Copepoda, Crustacea) derived from experiments with natural solar radiation. Photochem. Photobiol. 72, 314-319.

Utermöhl, H. 1931: Neuge wege in der quantitative erfassung des planktons (mit besonderer Berücksichtigung des Ultraplanktons). (New methods in the quantitative registration of plankton [with special emphasis on ultraplankton].) Limnol. Oceanogr. 5, 567-596.

Wiborg, K. F. 1954: Investigations on zooplankton in coastal and offshore waters of western and northern Norway. Fiskeridirektoratets Skrifter Serie, Havundersøkelser 9(1). Oslo: Fisheries Directorate.

Wold, A. 2002: Vertical migration as a response to UVR stress in Calanus finmarchicus females and nauplii. MSc thesis, Dept. of Aquatic Bioscience, University of Tromsø.

Zagarese, H. E. \& Williamson, C. E. 2000: Impact of solar UV radiation on the zooplankton. In S. D. Mora et al. (eds): The effects of $U V$ radiation in the marine environment. $\mathrm{Pp}$. 279-309. Cambridge: Cambridge University Press. 